\title{
An Approach to the Assessment of Transformational Leadership Competencies among Undergraduate Students
}

\section{Una propuesta de evaluación de las competencias de liderazgo transformacional en los estudiantes de licenciatura}

\section{DOI: $\underline{10.32870 / \text { dse.v0i19.506 }}$}

\author{
Eduardo Raúl Díaz Gómez* \\ José Luis Espinosa Garza** \\ Heberto Xavier Peterson Rodríguez ${ }^{* * *}$ \\ Ingrid Kuri Alonso****
}

\begin{abstract}
Faculty members from a higher education institution in northwestern Mexico created the FORTES program, designed to develop leadership competencies among undergraduate students and thus contribute to their future success in life. To address the need to assess the FORTES program, educators asked the students enrolled in the program to respond to the Student Leadership Practices Inventory (S-LPI). The results of the survey suggest that the leadership competencies of the students in the program are consistent with a transformational leadership model. This type of effort holds some promise to help narrow the gender gap in leadership education. The main contribution of this study is to provide educators involved in student leadership development outside the United States with an instrument to assess leadership competencies among students.
\end{abstract}

Key words: Student leadership - transformational leadership - gender gap.

\section{Resumen}

Miembros del personal docente de una universidad localizada en el noroeste de México crearon el programa FORTES con el propósito de formar líderes entre sus estudiantes de pregrado y, a su vez, contribuir al enriquecimiento de la vida futura de los alumnos. Ante la necesidad de evaluar la efectividad del programa, los estudiantes que participan en FORTES contestaron el Inventario de Prácticas de Liderazgo para Es-

* Ph.D. in Leadership. CETYS University, Tijuana Campus. Tijuana, Baja California, Mexico. eduardo.diaz@cetys.mx

** Master in Theology. Full-time professor at the College of Social Sciences and Humanities of CETYS University, Tijuana Campus. Mexico. joseluis. espinosa@cetys.mx

*** Candidate for an Inter-Institutional Ph.D. in Education. Coordinator of Humanities at the College of Social Sciences and Humanities of CETYS University, Tijuana Campus. Mexico. heberto.peterson@cetys.mx

**** Ph.D. in Social Science with a Specialization in Economic Development and Social Exclusion. Full-time professor at the College of Social Sciences and Humanities of CETYS University, Tijuana Campus. Mexico. ingrid.kuri@cetys.mx 
tudiantes (IPL-E). Los resultados de la encuesta sugieren que las competencias de liderazgo de los estudiantes inscritos en el programa son congruentes con un modelo de liderazgo transformacional y que este tipo de evaluaciones puede ayudar a reducir la brecha de género en la educación sobre liderazgo. La principal contribución de este estudio es proveer a otros educadores interesados en promover el liderazgo estudiantil fuera de Estados Unidos con una forma de medir las competencias de liderazgo de sus estudiantes.

Palabras clave: Liderazgo estudiantil - liderazgo transformacional - brecha de género.

Stakeholders in corporations, educational institutions, and society in general have placed great value on the role of leaders and leadership development efforts for the last few decades (Northouse, 2016). Consequently, leadership education has become an important part of the learning experience of students, which prompts educators to address leadership development in school (Eacott, 2012). As a result, undergraduate students have strengthened their leadership capacity during their college years (Hall, Forrester \& Borsz, 2008; Patterson, 2012; Fischer, WieIkiewicz, Stelzner, Overland \& Meuwissen, 2015). The importance assigned to leadership education is consistent with the challenges that need to be addressed by contemporary organizations. Leaders today are addressing changes in terms of technology, employee attitudes, types of responsibility, and organizational structures (Van Wart, 2013). They are also reasserting and promoting the importance of ethical conduct (Finley, 2012; Pucic, 2015). All of this while adjusting to the demands a culturally diverse and community-oriented society (Soria, Snyder \& Reinhard, 2015).

Educators have a role in promoting their students' leadership development through curricular and co-curricular programs (Burbank, Odom \& Sandlin, 2015; Posner, Crawford \& Denniston-Stewart, 2015). Seemiller and Murray (2013) noted that institutions of higher education are developing leadership competencies among their students, and that their leadership development programs could benefit by finding comparable methods to assess them. This would allow for comparisons among groups of students. One way in which educators have developed their evaluations of student leadership practices has been through the use of Kouzes and Posner's (2012) five practices of exemplary leadership model. This model is used to measure five leadership dimensions (model the way, inspire a shared vision, challenge the process, enable others to act, encourage the heart) that are associated with transformational leadership theory (Northouse, 2016). These five leadership dimensions are assessed through survey research using the Student Leadership Practices Inventory (S-LPI) self and/or observer forms.

The present study will address the need of educators in one private university in the northwest of Mexico to assess the leadership practices of their undergraduate students in a manner 
consistent with the evaluations of other groups of students. To develop leadership competencies among their students, the faculty at the University in question developed the FORTES program, which will be described in detail in the following section. The problem is that now that the program is entering its second phase, educators need to able to assess its effectiveness. The purpose of the present study is to develop an understanding of the leadership behaviors of the participants and identify potential areas for improvement. It has been argued that pedagogy and learning environment may affect the way students learn about leadership (Odom, 2015). By having a better understanding of student self-perceptions of leadership, educators responsible for running the FORTES program may be able to make adequate adjustments and ensure its sustainability.

The study will also serve to add to the efforts made by educators to assess the leadership behaviors of their students through the use of the S-LPI, which can facilitate comparisons among groups of students. In this case, the student group under analysis is located in Mexico. To this purpose, S-LPI mean scores were obtained from the participants and independent samples $\mathrm{t}$-tests were calculated to identify potential gender influence. The reason gender was added as a variable is the fact that leadership equity between males and females in the country is yet to be achieved (Moctezuma Navarro, Narro Robles \& Orozco Hernández, 2014; Zabludovsky Kuper, 2015).

On the topic of cultural diversity and leadership, Hunt and Conger (1999) examined several contributions to the study of transformational leadership and noted that more work is needed to address leadership efficacy and culture. These efforts may be addressed as part of the larger question of equity and equality in education, an issue that is being discussed in the literature on education (Valle Aparicio, 2013). The present study was developed to produce data on transformational leadership from college students in Mexico. This should help partial address Hunt and Conger's (1999) recommendation for future research. Hopefully, other educators in different parts of the world who share similar concerns regarding leadership development among students will find this approach useful, and the results of this study may be transferable.

\section{The FORTES program}

The Student Strength (FORTES, using the acronym in Spanish) program was developed by the department of Integrative Development of one private university in northwestern Mexico with the goal of promoting student life on campus through a clearly defined social agenda. It is a twoyear, co-curricular program designed for undergraduate students who have expressed interest in addressing societal problems through direct engagement. Students in the FORTES program were recruited based on their desire to engage social issues that affect their communities and society in general. They were also chosen based on their perceived leadership potential. The aim of the program is to build on the strengths of the students and their willingness to make a 
difference in their communities, especially on issues that affect underrepresented groups. The main audience for the program are the students themselves. They are the ones who receive the training and direction to develop their leadership potential and who are placed in positions to promote change. The skills and behaviors they develop by participating in the program are quite valuable given their relevance to their future social and organizational roles. In this sense, the FORTES program will serve the students long after graduation.

However, given the nature of the program, the beneficiaries of the program include a much larger segment of the population, especially individuals who belong to underrepresented groups in the Baja California region whose needs are studied and addressed as part of the FORTES program. These groups may be served by the program in the medium and long-term.

FORTES students are expected to participate in the program by moving through three phases:

1. Phase one: Understanding and contextualizing the implications of a situation or phenomenon.

2. Phase two: Analyzing and defining their position on an issue.

3. Phase three: Taking action by finding innovative solutions to clearly identified problems.

During phase one, students interact with community and regional leaders who help them understand current problems on a variety of issues. These interactions represent opportunities for the students to become educated about matters that need to be addressed by implementing innovative and distinctive strategies for improvement. Then, during phase two, students in the FORTES program are expected to take a position and determine the value or merit of a particular course of action on an issue. Finally, in phase three, the students exploit their leadership capabilities by influencing others to support initiatives to intervene in favor of groups whose needs have been undermined. At this point, the leadership skills, behaviors and creativity of the students become increasingly important to the successful completion of their activities and the success of the FORTES program itself.

The first cohort of students were entering their second year in the program at the time of this writing. At this point, they have moved past phase one. During their sophomore year, they have developed relationships with opinion leaders from several social and business organizations that operate under similar values to the ones guiding the FORTES program. However, these relationships are only beginning to be leveraged to promote the social agenda that is at the heart of the program. The first cohort of FORTES students is on schedule to conclude phase two and initiate phase three while the second cohort is only starting to be integrated into the program. With this in mind, it seemed prudent to objectively assess the leadership behaviors of the students in the first cohort of FORTES students. This will help identify differences in leader- 
ship behaviors among participants that may be used to compare different groups of students and establish appropriate benchmarks that students and educators can use to set goals for their educational programs.

\section{Review of the literature}

The present study was designed to evaluate the leadership practices of FORTES students using Kouzes and Posner's (2012) transformational leadership model. The data was collected through the S-LPI self, which suggest that the information that derived from the survey represents the self-perceptions of the participants involved in the study. Therefore, the study can be considered a measure of transformational leadership self-efficacy. Posner (2012) analyzed 77,387 responses to the S-LPI. His data were obtained through the work of other researchers studying student leadership in high schools and colleges. Posner (2012) was able to group these data and develop information to assess the parametric properties of the S-LPI and compare scores from different ethnic, national, academic, and gender groups. Given its wide use and application, the S-LPI represents a good choice for the development of student leadership assessment in a way that is comparable from one group of students to another.

The first part of this review of the literature is used to describe transformational leadership and the importance of leadership self-efficacy. This serves the purpose of providing the necessary theoretical support for the approach taken to develop the study. The second part of the review of the literature is used to address the issue of gender differences and leadership. This distinction will further serve to support the theoretical approach taken to develop the study. The third part of the review of the literature is used to describe Kouzes and Posner's (2012) five practices of exemplary leadership model. This will prove crucial for understanding the implication set forth in the Discussion section of this paper, which serves to describe the practical applications of the information that resulted from this study.

\section{Transformational Leadership Self-Efficacy}

In accordance with new demands for morally conscious leaders, there seems to be a shift in leadership as the new generation of leaders embrace the transformational approach and start the leave behind earlier leadership approaches (Murray \& Chua, 2014). The works of Burns (2010) and Bass (1985) were instrumental in documenting the rise and influence of transformational leadership theory as a leadership approach that leveraged transactional relationships, charismatic qualities of the leaders, and morality. Keating, Rosch, and Burgoon (2014) argued that successful leaders engage in effective transformational and transactional behaviors, are confident in their ability to lead, and are motivated to do so. The increased level of importance placed on student leadership development over the last few decades has led to worthy efforts made by educational leaders to increase leadership self-efficacy among undergraduate students. Several 
studies have been used to argue that it is very important for educators to understand predictors of leadership in students to develop appropriate strategies aligned with student leadership development (Wisner, 2011; Caza \& Rosch, 2014; Soria, Snyder \& Reinhard, 2015).

If problems in student leadership self-efficacy persist over time, these may affect their work during adulthood. Courtright, Colbert, and Choi (2014) studied 153 leaders working in fortune 500 companies and cautioned that low leadership self-efficacy could cause leaders to experience higher levels of stress and burnout than leaders with high leadership self-efficacy when addressing challenging assignments. Some of the strongest predictors of effective leadership in students include being self-aware and having the ability to relate to others (Wisner, 2011), and self-efficacy (Watson, Donovan \& Ruble, 2010; Keating et al., 2014; Burbank et al., 2015). Moreover, Barbuto (2000) noted that it is important for educators to understand the initial conditions of their students, so they can adjust their pedagogy and perform adequately.

Regarding the importance of assessing student leadership self-efficacy, Keating et al. (2014) noted that students with low leadership self-efficacy who participated in leadership training showed less improvement in terms of leadership efficacy than students with moderate or high initial self-efficacy. A situation like this one clearly has implications for the success of the leadership training program, which educators should adjust to. Therefore, it makes sense for individuals interested in helping their students develop their leadership potential through formal education programs to take steps to monitor their students'leadership self-efficacy scores. Burbank et al. (2015) used the S-LPI to measure leadership-self efficacy in students enrolled in one leadership course during their junior year. The students were asked to respond to the SLPI on two separate occasions and reflect on what they believed were the reasons for changes in scores in the survey. Students who did not report any change in scores were also asked to reflect and report on the reasons behind that outcome.

The implication of Burbank et al.'s (2015) study was that having students measure their leadership efficacy and participate in formal leadership development programs increases their consciousness in terms of strengths and weaknesses and develops a better appreciation for their own leadership capabilities. They added that curricular and co-curricular programs that create opportunities for students to engage in leadership practices were perceived favorably by students who are in the process of developing their leadership behaviors through formal education. Posner et al. (2015) developed a three-year study to assess leadership development in undergraduate students. They used the S-LPI to gather responses from Canadian students during their first, second, and third years of college. The findings suggest that leadership development is moderated by academic program, and not by gender, place of residence, or place of origin. Posner et al.'s (2015) study, along with work conducted by Caza and Rosch (2014) point to the value of doing research like this outside the United States. While researchers have studied issues of diversity like race and how they moderate leadership development (Kodama \& Dugan,

Diólo@os sobre Educación TEMAS ACTUALES EN INVESTIGACION : año 10 | número 19 | julio-diciembre 2019 | ISSN 2007-2171 
2013), more work is needed in other countries. The present study is an effort to address this concern.

Research in foreign countries conducted with young adults may best be served by framing the studies under the transformational leadership approach. Mortensen et al. (2014) confirmed that younger generations will likely identify better with the relatively recent leadership approaches (like transformational leadership) than with earlier theories. The present study, which was conducted in Mexico, was framed under Kouzes and Posner's (2012) five practices of exemplary leadership model, which is a well-established transformational leadership framework (Northouse, 2016). The model will be described in detail as part of this review.

\section{Leadership Approach and Gender.}

In Mexico, there continues to be a considerable gap in leadership roles between males and females (Moctezuma Navarro et al., 2014; Zabludovsky Kuper, 2015). Even though Posner et al. (2015) concluded that gender does not moderate leadership development among undergraduate students, their study was developed in Canada, so their results may not be transferable to groups of students in Mexico. In a study conducted with 92 undergraduate students in the United States, Rosch, Boyd, and Duran (2014) found that males and females tend to establish their leadership goals differently. These researchers argued that women in the study indicated having greater interest for developing leadership traits than specific skills or behaviors. The men in the study indicated greater interest for developing specific leadership skills. Previous works on leadership and gender designed to compare male and female leadership characteristics or traits (Schein, 1973; Schein, 1975; Cohen, Ornoy \& Keren, 2013) have served to suggest that male personality is more closely aligned with leader effectiveness than female personality. These findings have prompted some scholars to question whether the trait leadership approach can be used effectively to assess female leadership potential (Chemers, 2000; Jogulu Wood, 2006).

Since men continue to dominate top management positions in large corporations (Eagly \& Carli, 2007), it is understandable that undergraduate female students may feel the need to adopt a masculine approach to leadership. This strategy, however, may hurt them in the longterm for failing to comply with longstanding expectations regarding female roles in leadership positions (Leskinen, Rabelo \& Cortina, 2015). Works conducted under transformational leadership models have proven to be more appropriate for assessing leadership in aspiring and actual female leaders (Bass, Avolio \& Atwater, 1996; Eagly, Johannesen-Schmidt \& van Engen, 2003). Moreover, the transformational approach seems to be more aligned with present day aspirations of leaders and their environments (Murray \& Chua, 2014). Rosch et al.'s (2014) findings suggest that the men in their study are more concerned with developing the proper skills to become effective leaders. The skills approach was developed by Katz (1955) as part of 
the University of Michigan studies in response to the failure of the traits approach to develop a consistent set of characteristics that decision-makers could use to identify effective leaders (Northouse, 2016). Katz's (1955) approach was effective in introducing the notion that leaders could be developed through training designed to enhance the proper management skills.

Katz's (1955) model was developed based on technical, human and conceptual skills that leaders could develop over time as they went through the different hierarchical levels within organizations. While this model provides a logical and actionable approach to leadership development, it does not have the theoretical support other approaches have developed over the years (Northouse, 2016). On the other hand, Kouzes and Posner's five practices of exemplary leadership, a prominent transformational leadership model, has been widely used to measure student leadership (Posner, 2012). Rather than using personality leadership models, which have been found to be biased against female leaders (Eagly \& Carli, 2007), or skills based models, which lack theoretical support (Northouse, 2016), the present study was grounded on transformational leadership theory to ensure strong theoretical foundation and gender objectivity.

\section{The Five Practices of Exemplary Leadership Model}

Kouzes and Posner (2012) developed the five practices of exemplary leadership model by interviewing student leaders and asking them to talk about personal best experiences (Kibler, 2009). The five practices in the model can be described as follows:

1. Model the Way: How student leaders align personal, group, and organizational interests in a manner consistent with personal values.

2. Inspire a Shared Vision: How student leaders articulate a vision for the group that is consistent with the overall goals of the individuals involved.

3. Challenge the process: How student leaders approach innovation and identify opportunities to deliver superior results.

4. Enable Others to Act: How student leaders develop a trusting environment within the group and enhance collaboration.

5. Encourage the Heart: How student leaders celebrate the achievements of others and provide adequate recognition (Posner, 2012).

These five leadership dimensions can be assessed through the S-LPI. This 30-item questionnaire uses a 5-point Likert scale to measure the frequency with which students engage in the behaviors associated with each of the five practices. Further detail on this instrument is provided in the Methods section. Kouzes and Posner's model has proven useful for aspiring leaders and educators charged with developing leadership behaviors with their students (Kibler, 2009). Along with Bass's (1985) Multifactor Leadership Questionnaire (MLQ), the LPI and S-LPI are 
among the most widely used transformational leadership instruments (Northouse, 2016). To illustrate the widespread use of the S-LPI to assess student's leadership competencies, Posner (2012) conducted an analysis of several works developed by leadership educators in many parts of the world outside the United States. Table 1 provides a summary of some of his findings.

Table 1. S-LPI Scores for Students Outside the United States

\begin{tabular}{llll}
\hline S-LPI dimensions & $\mathrm{N}$ & Mean & SD \\
\hline Model the way & 3,336 & 20.8 & 3.6 \\
Inspire a shared vision & 3,336 & 20.4 & 4.2 \\
Challenge the process & 3,336 & 20.7 & 4.0 \\
Enable others to act & 3,336 & 23.7 & 3.2 \\
Encourage the heart & 3,336 & 22.5 & 3.9 \\
\hline
\end{tabular}

Note: Developed by the author with data from Posner (2012).

\section{Research questions}

To properly obtain actionable information regarding the leadership practices of FORTES students, the present study was designed to address the following questions:

1. What are the mean scores of FORTES students in each of the five dimensions measured through the S-LPI?

2. Are there statistically significant differences between male and female participants for each of the leadership practices measured through the S-LPI?

The second question guiding this study was added to determine whether gender affects leadership self-efficacy among the FORTES students. As noted earlier, there is still evidence that suggest that gender equity in Mexico remains an unrealized goal (Moctezuma Navarro et al.; Zabludovsky Kuper, 2015).

\section{Method}

The present study was conducted following the quantitative tradition using survey research (Fowler, 2014) to assess the leadership practices of students involved with the FORTES program. To address the first research question, descriptive statistics were employed to document mean scores in each S-LPI dimension. To identify differences between males and females, independent samples t-test were employed. Note that t-test may be used with small sample sizes like the one in this study. To address the second research question, the study was designed consistently with post facto research (Abbott \& McKinney, 2013) because the participants were not altered as part 
of the study. However, the effect of the independent variable (gender) was examined in terms of how it affected the dependent variables (the five leadership practices measured with the S-LPI).

\section{Participants}

Forty-six CETYS Universidad undergraduate students who are active participants in the FORTES program completed the S-LPI questionnaire. Forty-eight percent of the participants were enroIled in the Mexicali campus, 28 percent in the Tijuana campus, and 24 percent in the Ensenada campus. Students from the College of Business and Administration (CBA) accounted for approximately 70 percent of the participants, while students from the College of Engineering (CE) and students from the College of Social Sciences and Humanities (CSSH) accounted for 22 and nine percent, respectively. Overall, 46 percent of total FORTES students participated in the survey.

The participants were part of a purposive sample (Creswell, 2014). All students involved with the FORTES program were invited to participate in the study at one of their weekly meetings. They were provided with an informed consent form and the S-LPI self, and they were asked to complete and return the forms at their convenience over the course of one week. Students who declined to participate did not return the forms. Those who participated in the study returned their signed consent forms and the completed S-LPI self-form to the faculty managers of the FORTES program. The students were asked to indicate their gender, campus, and College/ School in which they are enrolled. The students were made aware that participating in the study was a voluntary activity and that their identities were not to be published or associated with individual cores.

\section{Instrument}

The S-LPI consists of 30 items designed to measure the five practices of exemplary leadership in Kouzes and Posner's model (2012). The five practices are: (1) model the way, (2) inspire a shared vision, (3) challenge the process, (4) enable others to act, and (5) encourage the heart. Each item in the S-LPI is evaluated using a 5-point Likert scale. The S-LPI consistently meets the norms for reliability and validity (Posner, 2012). After analyzing a database of 77,387 students, Cronbach alpha coefficients were calculated and met reliability standards, and predictive validity was confirmed for the self and observer versions of the instrument (Posner, 2012). The S-LPI was administered in its paper version. Permission to use the instrument was obtained from the publisher approximately one month before the participants were approached with the invitation to take the survey. The completed S-LPI forms are kept under lock in a cabinet located in the office of one of the authors of this paper.

\section{Procedure}

Several steps were taken to ensure that the data collection phase of the present study was conducted effectively and ethically. First, permission to use the S-LPI for academic purposes was 
obtained in writing from the publisher of the instrument. Second, students were verbally invited to participate in the study during one of their weekly FORTES meetings. Third, students who agreed to participate after the initial invitation were given informed consent forms to read, sign, and return. Last, the S-LPI was administered in its paper form to FORTES students who signed and returned their consent forms. The participants were given one week to return their completed forms. All participants in the study were age 18 or above.

\section{Data Analysis}

The data collected through the S-LPI questionnaires was processed with the assistance of the Statistical Package for the Social Sciences (SPSS) software. The analysis consisted of running descriptive statistics to identify mean scores, and independent samples t-tests to compare mean scores between males and females for each of the five leadership practices measured through the S-LPI. Alpha levels were set at .01 to minimize Type I error.

To facilitate the analysis, the items of the S-LPI were grouped according to their corresponding dimensions:

1. Model the Way: Items 1, 6, 11, 16, 21, 26.

2. Inspire a Shared Vision: Items 2, 7, 12, 17, 22, 17.

3. Challenge the Process: Items 3, 8, 13, 18, 23, 28.

4. Enable Others to Act: Items 4, 9, 14, 19, 24, 29.

5. Encourage the Heart: Items 5, 10, 15, 20, 25, 30.

Once the data analysis phase was completed, the results were stored in a password protected laptop that is kept on a locked office. Furthermore, the names of the participants were not included in any of the reports created to interpret the data.

\section{Results}

The two research questions that were drafted to guide this study were addressed through descriptive statistics and independent samples t-tests. The data displayed in Table 2 and Table 3 represent the responses to questions one and two, respectively.

1. What are the mean scores of FORTES students in each of the five dimensions measured through the S-LPI? 
Table 2. FORTES students S-LPI Mean Scores

\begin{tabular}{lllll}
\hline S-LPI dimensions & Mean & SD & Min. & Max. \\
\hline Model the way & 23.5 & 3.2 & 16.00 & 29.00 \\
Inspire a shared vision & 24.1 & 3.4 & 12.00 & 30.00 \\
Challenge the process & 23.8 & 3.3 & 16.00 & 30.00 \\
Enable others to act & 24.3 & 3.6 & 15.00 & 30.00 \\
Encourage the heart & 24.6 & 3.5 & 16.00 & 30.00 \\
\hline
\end{tabular}

2. Are there statistically significant differences between male and female participants for each of the leadership practices measured through the S-LPI?

Table 3. Independent Samples t-tests for Male and Females Participants

\begin{tabular}{lllllll}
\hline S-LPI dimensions & Male & \multicolumn{7}{l}{ Female } \\
\hline & Mean & SD & Mean & SD & t & P \\
Model the way & 23.5 & 3.4 & 23.4 & 3.1 & .140 & .890 \\
Inspire a shared vision & 24.5 & 4.1 & 23.8 & 2.9 & .602 & .550 \\
Challenge the process & 24.2 & 3.7 & 23.5 & 3.0 & .669 & .507 \\
Enable others to act & 24.8 & 3.4 & 23.9 & 3.7 & .826 & .413 \\
Encourage the heart & 24.5 & 3.2 & 24.7 & 3.6 & -.125 & .901 \\
\hline
\end{tabular}

The data on Table 2 and Table 3 are consistent with the nature of the research questions that guided the present study. The importance and application of the data are discussed in the following section.

\section{Discussion and Future Research}

The present study was designed to assess the leadership practices of FORTES students in a way that allows educators responsible for the program to identify strengths and weaknesses and make the proper adjustments. In the process, the study would add to the literature on student leadership practices in Mexico. Posner et al. (2015) argued that student leadership practices may be developed throughout the time period they engaged in their undergraduate programs, and that identifying changes in student leadership behavior may help educational leaders learn about the effectiveness of their programs and promote an environment where better informed decisions get made in favor of student leadership development. Comparatively, the participants in this study delivered high mean scores in each of the leadership practices described in Kouzes and Posner's (2012) model. As illustrated in Table 1 and Table 2, the FORTES students scored higher in each S-LPI dimension than students from countries outside the United States who have participated in leadership studies involving the S-LPI. 
Beyond turning up a favorable comparison for FORTES students in terms of their leadership self-efficacy, simply measuring their leadership practices can enhance their leadership development experience. As noted before, reflection and self-awareness are value components of leadership education programs (White \& Guthrie, 2016). With the data presented here, educators responsible for the FORTES program can make their students aware of their leadership profile and generate discussions on the meaning of the results for each of the five practices of exemplary leadership. Moreover, these scores represent a benchmark that the participants and educators involved in the study can use to set goals, track changes, and make adequate adjustments. A new cohort of FORTES students may benefit from this initial assessment. The knowledge gained from this experience may be transferable to the next FORTES cohort and to other student-leadership training programs.

Concerns regarding the influence of gender on leadership in Mexico (Moctezuma Navarro et al.; Zabludovsky Kuper, 2015) did not manifest in the present study. Although male participants scored higher in four out of the five leadership practices measured through the S-LPI, these differences were not statistically significant (see Table 3). Moreover, the findings in the present study did not support the conclusions presented in previous studies under trait and behavioral leadership frameworks (Schein, 1973; Schein, 1975; Cohen, Ornoy \& Keren, 2013). The findings, however, were consistent with previous works on gender and leadership developed under transformational leadership theory (Bass, Avolio \& Atwater, 1996; Eagly, JohannesenSchmidt \& van Engen, 2003).

Potential leadership self-efficacy differences between female students who are involved with a leadership development program like FORTES and female students who are not involved with this kind of program may represent an interesting opportunity for further research. After a review of the literature, no study of this nature was identified to have taken place in Mexico. Another opportunity for future research is the application of the S-LPI to measure the leadership practices of a larger group of college students in Mexico. The present study was carried out with a relatively small group of participants, which limits the generalizability of the results.

\section{Conclusion and limitations}

Transformational leadership practices have been associated with superior organizational outcomes, but individuals from different cultures may tend to have conflicting ideas regarding what constitutes effective leadership (Gandolfi, 2012). Efforts like the Global Leadership and Organisational Behaviour Effectiveness (GLOBE) student project are being developed to address differences in perception of leader effectiveness among students from different parts of the world (Čarter, Lang \& Szabo, 2013). The present study contributes to the phenomenon of leadership development in students in several ways. First, it adds to the works developed by educators in different parts of the world who are making important efforts to develop future leaders 
through educational programs. Based on the findings presented in this study, leadership development programs can be effective.

Second, it addresses the problem of gender inequity in leadership roles in Mexico by analyzing the differences between male and female college students involved in a leadership development program. In this case, male and female participants have very similar levels of leadership self-efficacy. This may have important implications for aspiring and actual female leaders, and top managers assigned to recruit new leaders. Third, the study may serve educators interested in promoting leadership development as a benchmark they can use to set goals and measure progress. Finally, the methodology used to conduct this study may be replicated by educators in different parts of the world who are interested in assessing the effectiveness of their leadership programs in a way that produces data that may be used to make cross-cultural and inter-institutional comparisons.

The main limitation encountered in conducting the study is the small number of participants. Because there were only 46 participants in the study, the data could not be used to further test the parametric properties of the S-LPI. Also, since this was a purposive sample, the results cannot be generalizable to other groups of students. Another limitation was the fact that the study was based on self-reported data only. Although the study was designed to measure self-perceptions, relying on self-reports may invite the potential for bias. Nonetheless, this is a fair case of an effort to standardize leadership development under transformational approaches in Mexico.

\section{References}

Abbott, M. L. \& J. McKinney (2013). Understanding and applying research design. Somerset, US: Wiley.

Barbuto Jr., J. E. (2000). Developing a leadership perspective in the classroom. Journal of Adult Development, 7(3), 161.

Bass, B. M. (1985). Leadership: Good, better, best. Organizational Dynamics, 13(3), $26-40$.

B. J. Avolio \& L. Atwater, (1996). The transformational and transactional leadership of men and women. Applied Psychology: An International Review, 45(1), 5-34. doi:10.1111/j.1464-0597.1996.tb00847.x

Burbank, M., S. Odom \& M. Sandlin (2015). A content analysis of undergraduate students' perceived reasons for changes in personal leadership behaviors. Journal of Leadership Education, 14(2), 182-197. doi:10.12806/V14/I2/R12

Burns (2010). Leadership. New York, NY, Harper Perennial Political Classics.

Čarter, T., R. Lang \& E. Szabo (2013). Values and leadership expectations of future managers: Theoretical basis and methodological approach of the GLOBE Student project. Journal for East European Management Studies, 18(4), 442-462.

Diólo pos 
Caza, A. \& D. M. Rosch (2014). An exploratory examination of students' pre-existing beliefs about leadership. Studies in Higher Education, 39(9), 1586-1598. doi:10.1080/03075079.2013.801434

Chemers, M. M. (2000). Leadership research and theory: A functional integration. Group Dynamics: Theory, Research, and Practice, 4(1), 27-43. doi:10.1037/1089-2699.4.1.27

Cohen, Y., H. Ornoy \& B. Keren (2013). MBTI personality types of project managers and their success: A field survey. Project Management Journal, 44(3), 78-87. doi:10.1002/pmj.21338

Courtright, S. H., A. E. Colbert \& D. Choi (2014). Fired up or burned out? How developmental challenge differentially impacts leader behavior. Journal of Applied Psychology, 99(4), 681696. doi: 10.1037/a0035790

Creswell, J. W. (2014). Research design: Qualitative, quantitative, and mixed methods approaches. (Fourth edition). Thousand Oakes, CA, Sage Publications.

Eacott,S.(2012).Introducingundergraduatestudentstoschoolleadershipconcepts.JournalofEducational Administration, 50(2), 159-172. doi: http://dx.doi.org/10.1108/09578231211210521

Eagly, A. H. \& L. L. Carli, (2007). Through the labyrinth: The truth about how women become leaders. Boston, MA, Harvard Business Review.

M. C. Johannesen-Schmidt \& M. L. van Engen, (2003). Transformational, transactional, and laissez-faire leadership styles: A meta-analysis comparing women and men. Psychological Bulletin, 129(4), 569-591. doi:10.1037/0033-2909.129.4.569

Finley, S. (2012). Servant leadership: A literature review. Review of Management Innovation \& Creativity, 5(14), 135-144.

Fischer, D. d., R. r. Wielkiewicz, S. s. Stelzner, M. m. Overland \& A. S. Meuwissen, (2015). Changes in Leadership Attitudes and Beliefs Associated with the College Experience: A Longitudinal Study. Journal of Leadership Education, 14(1), 14-32. doi:1012806/V14/I1/R10

Fowler, F. J. (2014). Survey research methods. (Fifth edition). Thousand Oakes, CA, SAGE Publications.

Gandolfi, F. (2012). A conceptual discussion of transformational leadership and intercultural competence. Review of International Comparative Management / Revista De Management Comparat International, 13(4), 522-534.

Hall, S. L., S. Forrester \& M. Borsz (2008). A constructivist case study examining the leadership development of undergraduate students in campus recreational sports. Journal of College Student Development, 49(2), 125-140.

Hunt, J. \& J. A. Conger (1999). From where we sit: An assessment of transformational and charismatic leadership research. Leadership Quarterly, 10(3), 335.

Jogulu, U. D. \& G. J. Wood (2006). The role of leadership theory in raising the profile of women in management. Equal Opportunities International, 25(4), 236-250. doi: http://dx.doi. org/10.1108/02610150610706230

Katz, R. L. (1955). Skills of an effective administrator. Harvard Business Review, 33(1), 33-42. 
Keating, K., D. D. Rosch \& L. B. Burgoon (2014). Developmental readiness for leadership: The differential effects of leadership courses on creating "ready, willing, and able" leaders. Journal of Leadership Education, 13(3), 1-16.

Kibler, W. L. (2009). The student leadership challenge: Five practices for exemplary leaders. NASPA Journal (National Association of Student Personnel Administrators, Inc.), 46(4), 710-715.

Kodama, C. C. \& J. P. Dugan (2013). Leveraging leadership efficacy for college students: Disaggregating data to examine unique predictors by race. Equity \& Excellence in Education, 46(2), 184-201. doi:10.1080/10665684.2013.780646

Kouzes, J. M. \& B. Z. Posner (2012). The leadership challenge: How extraordinary things happen in organizations. (Fifth edition). San Francisco, CA, Leadership Challenge.

Leskinen, E. A., V. C. Rabelo \& L. M. Cortina (2015). Gender stereotyping and harassment: A 'catch-22' for women in the workplace. Psychology, Public Policy, and Law, 21(2), 192-204. doi:10.1037/law0000040

Moctezuma-Navarro, D., J. Narro-Robles \& L. Orozco-Hernández (2014). La mujer en México: Inequidad, pobreza y violencia. Revista Mexicana de Ciencias Políticas y Sociales, 59(220), 117 146

Mortensen, J., L., Lichty, P. Foster-Fishman, S. Harfst, S. Hockin, K. Warsinske \& K. Abdullah (2014). Leadership through a youth lens: understanding youth conceptualizations of leadership. Journal of Community Psychology, 42(4), 447-462. doi:10.1002/jcop.21620

Murray, D. \& S. Chua (2014). Differences in leadership styles and motives in men and women: How generational theory informs gender role congruity. Proceedings of the European Conference on Management, Leadership \& Governance, 192-199.

Northourse, P. G. (2016). Leadership: Theory and practice (seventh edition). Thousand Oakes, CA, SAGE Publication.

Odom, S. F. (2015). Undergraduate student perceptions of the pedagogy used in a leadership course: A qualitative examination. Journal of Leadership Education, 14(2), 17-29. doi:10.12806/V14/I2/R2

Patterson, B. (2012). Influences of student organizational leadership experiences in college students leadership behaviors. E Journal of Organizational Learning \& Leadership, 10(1), 1-12.

Posner, B. Z. (2012). Effectively measuring student leadership. Administrative Sciences (20763387), 2(4), 221-234. doi:10.3390/admsci2040221

B. Crawford \& R. Denniston-Stewart (2015). A longitudinal study of Canadian student leadership practices. Journal of Leadership Education, 14(2), 161-181. doi:10.12806/V14/I2/R11

Pucic, J. (2015). Do as I say (and do): Ethical leadership through the eyes of lower ranks. Journal of Business Ethics, 129(3), 655-671. doi:10.1007/s10551-014-2190-z

Rosch, D. d., B. b. Boyd \& K. k. Duran (2014). Students' self-identified long-term leadership development goals: An analysis by gender and race. Journal of Leadership Education, 13(3), 17-33. 
Seemiller, C. \& T. Murray (2013). The common language of leadership. Journal of Leadership Studies, 7(1), 33-45. doi:10.1002/jls.21277

Schein, V. E. (1973). The relationship between sex role stereotypes and requisite management characteristics. Journal of Applied Psychology, 57(2), 95-100.

(1975). Relationships between sex role stereotypes and requisite management characteristics among female managers. Journal of Applied Psychology, 60(3), 340-344.

Soria, K., S. Snyder \& A. P. Reinhard (2015). Strengthening college students' integrative leadership orientation by building a foundation for civic engagement and multicultural competence. Journal of Leadership Education, 14(1), 55-71.

Valle-Aparicio, J. E. (2013). Educando en la diferencia: Liderazgo educativo en espacios de exclusión multidimensional. Diálogos sobre educación, 4(7), 1-20.

Van Wart, M. (2013). Lessons from leadership theory and the contemporary challenges of leaders. Public Administration Review, 73(4), 553-565. doi:10.1111/puar.12069

Watson, C., J. J. Donovan \& T. Ruble (2010). Assessing business students' leadership self-efficacy. Journal of Learning in Higher Education, 6(1), 19-26.

White, J. V. \& Guthrie, K. L. (2016). Creating a meaningful learning environment: Reflection in leadership education. Journal of Leadership Education, 15(1), 60-75. doi:1012806/V15/I1/R5

Wisner, M. D. (2011). Psychological strengths as predictors of effective student leadership. Christian Higher Education, 10(3/4), 353-375. doi:10.1080/15363759.2011.576223.

Zabludovsky-Kuper, G. (2015). Las mujeres en los ámbitos de poder económico y político de México. Revista Mexicana de Ciencias Politicas y Sociales, 60(223), 61-94. 